\title{
Prevalence of 'Candidatus Mycoplasma haemobos' detected by PCR, in dairy cattle from Ji-Paraná in the north region of Brazil
}

\author{
Rute Witter ${ }^{1}$ Andréia Lima Tomé Melo ${ }^{1}$ Thábata dos Anjos Pacheco ${ }^{1}$ Mirella Meneguzzi ${ }^{2}$ \\ Ricardo Vilas Boas $^{3}$ Valéria Dutra ${ }^{1}$ Luciano Nakazato ${ }^{1}$ Cristiane Silva Chitarra ${ }^{1}$ \\ Anderson Castro Soares de Oliveira ${ }^{1}$ Richard Campos Pacheco ${ }^{1 *}$
}

${ }^{1}$ Programa de Pós-graduação em Ciências Veterinárias, Faculdade de Medicina Veterinária, Universidade Federal de Mato Grosso (UFMT), 78060-900, Cuiabá, MT, Brasil. E-mail: richard@ufmt.br. "Corresponding author.

${ }^{2}$ Instituto de Biociências, Universidade Federal de Mato Grosso (UFMT), Cuiabá, MT, Brasil.

${ }^{3}$ Associação de Assistência Técnica e Extensão Rural do Estado de Rondônia, Ji-Paraná, RO, Brasil.

\begin{abstract}
The municipality of Ji-Paraná, Rondônia, is one of the major dairy production areas in the north region of Brazil. Thus, it is important to evaluate infectious agents that have the potential to negatively affect productivity in the industry. The objective of this study was to investigate the prevalence of 'Candidatus Mycoplasma haemobos' by using a PCR-based detection method and correlate this with dairy herd variables (abortion frequency, weak calf birth rate, total cattle number, >24-month-old cow number, farm size, and production system) in family farms of the Ji-Paraná municipality, north region, Brazil. Blood samples were collected from 320 dairy cows located across 64 farms (i.e., five animals per farm) from September 2012 to November 2013. Overall prevalence of 'Ca. M. haemobos' was 64.2\% and prevalence per herd was $95.3 \%$; the number of >24-month-old cows in the farms studied correlated with 'Ca. M. haemobos' infection rates. Considering the importance of the dairy industry to the study area, additional investigations are necessary to evaluate the effect of chronic infection in these animals on milk production and herd health.
\end{abstract}

Key words: hemoplasmas, hemotropic mycoplasmas, dairy herd.

Prevalência de 'Candidatus Mycoplasma haemobos' pela PCR, em bovinos

leiteiros de Ji-Paraná na região norte do Brasil

RESUMO: O municipio de Ji-Paraná, Rondônia, é uma das principais áreas de produção leiteira na região norte do Brasil. Assim, é importante avaliar agentes infecciosos que apresentam potencial para afetar negativamente a produtividade na indústria. O objetivo deste estudo foi investigar a prevalência de 'Candidatus Mycoplasma haemobos' usando um método de detecção baseado na PCR e relacionar com variáveis do rebanho leiteiro (frequência de aborto, nascimento de bezerros fracos, número total de vacas, número de vacas $>24$ meses de idade, tamanho da propriedade e, sistema de produção) na agricultura familiar do município de Ji-Paraná, região norte, Brasil. Amostras de sangue foram coletadas de 320 vacas leiteiras localizadas em 64 fazendas (ou seja, cinco animais por exploração) de setembro de 2012 a novembro de 2013. A prevalência total de 'Ca. M. haemobos'foi de 64,2\% e a prevalência por rebanho foi de 95,3\%; o número de vacas $>24$ meses de idade nas propriedades estudadas correlacionouse com as taxas de infecção por 'Ca. M. haemobos'. Considerando a importância da indústria de laticínios para a área de estudo, investigações adicionais são necessárias para avaliar o efeito da infecção crônica nestes animais na produção de leite e saúde do rebanho.

Palavras-chave: hemoplasmas, micoplasmas hemotrópicos, rebanho leiteiro.

\section{INTRODUCTION}

Hemotropic mycoplasmas, also known as hemoplasmas, are unculturable and cell wall-less bacteria whose infections cause anemia in several mammalian species by attaching erythrocytes (SMITH et al., 1990; MESSICK, 2004). Two distinct species have been identified in cattle, namely, Mycoplasma wenyonii (formerly Eperythrozoon wenyonii) (ADLER \& ELLENBOGEN, 1934) and a provisional species 'Candidatus Mycoplasma haemobos', also known as ' $\boldsymbol{C} \boldsymbol{a}$. M. hemobovis' (TAGAWA et al., 2008). Despite the worldwide distribution of both bovine hemoplasmas, 'Ca. M. haemobos' has only been reported in cattle from Switzerland (MELI et al., 2010), China (SU et al., 2010), Japan (TAGAWA et al., 2008), Germany (HOELZLE et al., 2011), Hungary (HORNOK et al., 2011), England (AYLING et al., 2012), New Zealand (MCFADDEN et al., 2016), and Brazil (GIROTTO et al., 2012). The latter refers to the only description of hemoplasma in cattle blood detected by PCR in the southern region of the country. It is difficult to interpret the pathogenic potential of bovine hemoplasma infections since co infection may contribute to hemoplasma pathogenicity in a synergistic manner, particularly when infection results in immunosuppression (MELI et al., 2010; MCFADDEN et al., 2016). Chronic infection in cattle can be asymptomatic (SMITH et 
al., 1990; MESSICK, 2004; TAGAWA et al., 2013); however, symptoms can be observed such as transient fever, anorexia lymphadenopathy, and weight loss in females and calves.

Decreased milk yield, abortion, and delayed estrus have been reported during the acute phase of hemoplasma infection in cattle (SMITH et al., 1990; MESSICK, 2004; TAGAWA et al., 2013). In addition, previous studies have observed the effect of hemoplasma infection on hematological parameters, suggesting that a degree of hemolytic anemia may have been present in infected cattle (TAGAWA et al., 2010; 2012). Regarding the epidemiology of hemoplasmas infections, in general, routes of infection remain uncharacterized; although mechanical and transplacental transmissions have been suggested (HORNOK et al., 2011).

In Brazil, effects of ' $\boldsymbol{C a}$. M. haemobos' occurrence and chronically infected asymptomatic carriers on dairy production have not been investigated. The objective of this study was to describe the prevalence of ' $\boldsymbol{C} \boldsymbol{a}$. M. haemobos' using a PCR-based detection method and correlate this with dairy herd variables in family farms of the Ji-Paraná municipality, north region, Brazil.

\section{MATERIALS AND METHODS}

This study was conducted in the municipality of Ji-Paraná $\left(10^{\circ} 52^{\prime} 42^{\prime \prime} \mathrm{S}, 61^{\circ} 56^{\prime}\right.$ 41 " W), in the state of Rondônia. Dairy cows were sampled from September 2012 to November 2013, alongside samples taken for an alternate study on the seroprevalence of Neospora caninum (BOAS et al., 2015). For sample collection, the municipality area was divided into six strata of milk production, referred to as rural sectors (Figure 1), in accordance with data from the Technical Assistance and Rural Extension Association of the state of Rondônia (EMATER-RO).

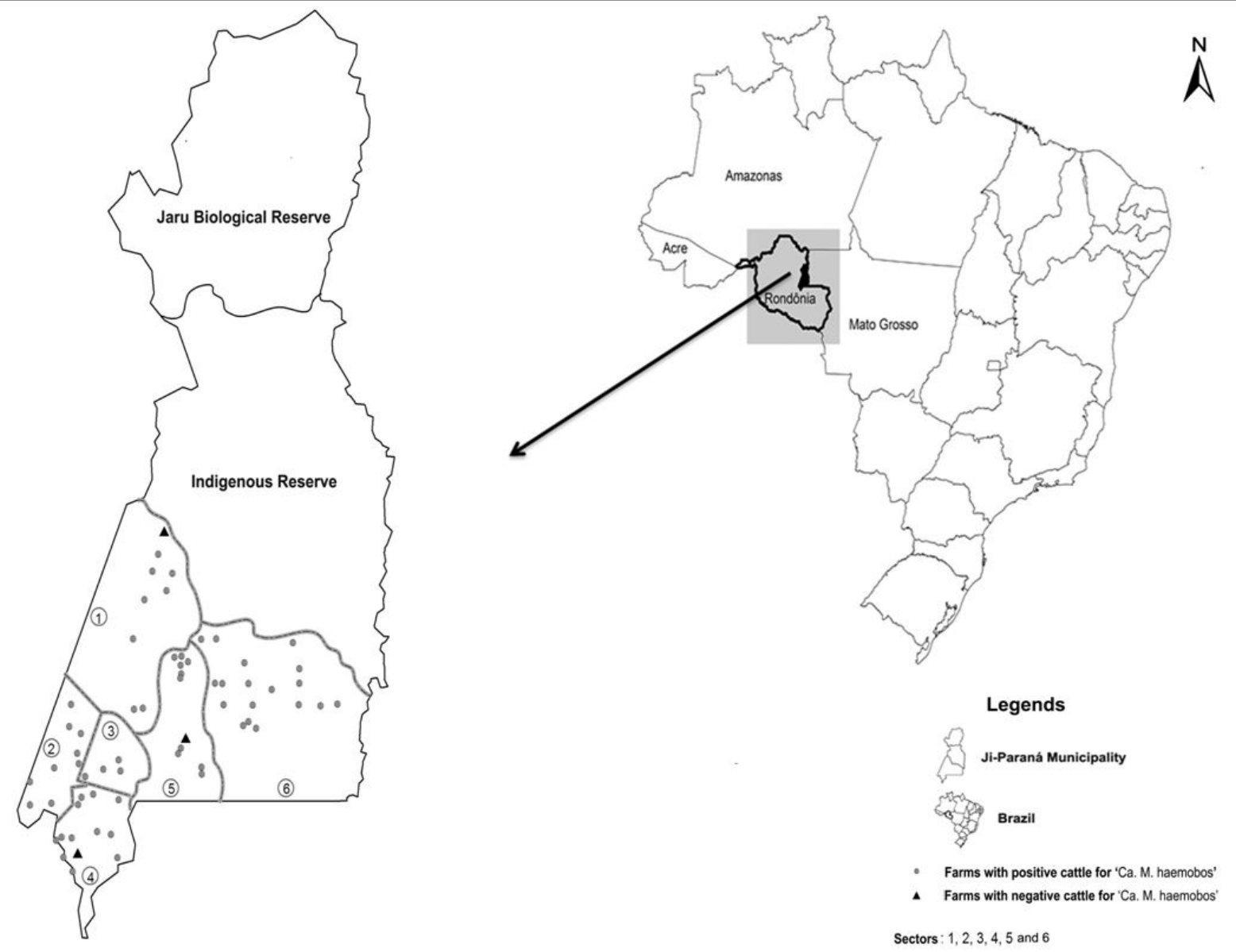

Figure 1 - Distribution of family farms surveyed in this study, which considered six strata of milk production (rural sectors), in accordance with data from the Technical Assistance and Rural Extension Association of the State of Rondônia (EMATER-RO), Ji-Paraná, Rondônia. 
Sample size was determined by the statistical formula $N_{0}=[N p(1-p) /(N-1)(d /$ $\left.\left.Z_{\alpha / 2}\right)^{2}+p(1-p)\right]$. deff with a population size of 34,527 animals, estimation of prevalence of $50 \%$, maximum error of $6 \%, 95 \%$ confidence interval, and design effect (deff) of 1.2. The estimation of prevalence was based on no previous studies in the region and that the maximum number of occurrences with normal distribution would be $50 \%$. The sample size was 320 animals with weighting according to the sampling design, and taking into consideration the probabilities of selection among the farms and animals (Table 1). Blood samples were collected from five $>24$-monthold dairy cows from each of the 64 family farms selected, and a questionnaire was given to each farmer for epidemiological data analysis.

DNA was extracted from blood samples using the phenol-chloroform method (SAMBROOK $\&$ RUSSEL, 2001) and stored at $-20^{\circ} \mathrm{C}$ until further use. DNA samples were tested for the presence of 'Ca. M. haemobos' using PCR analysis as previously described (GIROTTO et al., 2012). DNA from 'Ca. M. haemobos' (GenBank accession number JN314393) and nuclease free water were used as positive and negative controls, respectively. PCR products were analyzed by electrophoresis on $1.5 \%$ agarose gels, and positive samples were purified and then sequenced in an automated sequencer (ABI PRISM $^{\circledR} 3500$ ).

Partial sequences were subject to Basic Local Alignment Search Tool (BLAST; ALTSCHUL et al., 1990) analysis to identify those GenBank sequences with closest similarities. A phylogenetic tree based on $460 \mathrm{bp}$ partial sequences of $16 \mathrm{~S}$ rRNA was produced using the Neighbor-Joining Distance method (Figure 2). Bootstrap values, calculated from 1000 replicates, showed the percentage of replicate trees in which the associated ratio clustered together.
The phylogenetic tree, sequence alignments, and identity tables (data not shown) were created by using Molecular Evolutionary Genetics Analysis (MEGA) software version 5.0 (TAMURA et al., 2007).

Statistical analyses were performed using the $\mathrm{R}$ statistical package ( $\mathrm{R}$ DEVELOPMENT CORE TEAM, 2013). Correlations between the dairy herds that tested positive for ' $\boldsymbol{C a}$. M. haemobos' and the herd variables were analyzed by means of the chi-square $\left(\chi^{2}\right)$ test, with a significance of $5 \%$ applied. The considered herd variables were abortion frequency, weak calf birth rate, total cattle number, >24-month-old cow number, farm size (hectares), and production system.

\section{RESULTS}

Overall, 207 blood samples generated 16S rRNA amplicons specific for ' $\boldsymbol{C} \boldsymbol{a}$. M. haemobos', which equated to $64.2 \%$ prevalence in the total population (95\% CI: $58.68-69.37 \%)$. Across the six rural sectors in the municipality (Figure 1), at least one of the animals sampled from each dairy herd was positive for ' $\boldsymbol{C a}$. M. haemobos', with the exception of three farms located in sectors one, four, and five. This equated to $95.3 \%$ ' $\boldsymbol{C} \boldsymbol{a}$. M. haemobos' prevalence in herds (61/64; Table 1).

Seven samples positive for ' $\boldsymbol{C} \boldsymbol{a}$. M. haemobos', drawn from each of the six rural sectors, were sequenced. Comparison of partial $16 \mathrm{~S}$ rRNA (460bp) sequences yielded two haplotypes that differed by a single nucleotide polymorphism. BLAST analyses of these sequences showed 99$100 \%$ similarity to ' $\boldsymbol{C} \boldsymbol{a}$. M. haemobos' (GenBank EF616468). The 16S rRNA partial sequences generated in the present study were submitted to GenBank with the accession numbers KT314241 ('Ca. M. haemobos' isolate Ji-Parana/RO-1) and

Table 1 - Columns left to right: (1) Rural sector of the municipality of Ji-Paraná, Rondônia. (2) Total number of farms in the rural sector. (3) Number of farms sampled in the current survey. (4) Number of sampled farms positive for 'Candidatus Mycoplasma haemobos' infection, and the proportion of infected farms of all sampled farms. (5) Total number of $>24$-month-old dairy cows in the rural sector. (6) Number of cows sampled in the current survey. (7) Number of cows positive for 'Ca. Mycoplasma haemobos' infection, and the proportion of infected cows of all sampled cows. All data was collected from September 2012 to November 2013.

\begin{tabular}{|c|c|c|c|c|c|c|}
\hline $\begin{array}{l}\text { Rural } \\
\text { sector }\end{array}$ & N. of farms & $\begin{array}{l}\text { N. of farms } \\
\text { sampled }\end{array}$ & $\begin{array}{l}\text { N. of farms } \\
\text { positive }(\%)\end{array}$ & N. of dairy cows & $\begin{array}{c}\text { N. of dairy cows } \\
\text { sampled }\end{array}$ & $\begin{array}{c}\text { N. of dairy cows } \\
\text { positive }(\%)\end{array}$ \\
\hline 1 & 122 & 9 & $8(88.8)$ & 5,246 & 45 & $26(57.7)$ \\
\hline 2 & 124 & 9 & $9(100)$ & 5,952 & 45 & $29(64.4)$ \\
\hline 3 & 54 & 4 & $4(100)$ & 2,268 & 20 & $12(60.0)$ \\
\hline 4 & 176 & 13 & $12(92.3)$ & 8,096 & 65 & $36(55.3)$ \\
\hline 5 & 143 & 11 & $10(90.0)$ & 4,433 & 55 & $35(63.6)$ \\
\hline 6 & 237 & 18 & $18(100)$ & 8,532 & 90 & $69(76.6)$ \\
\hline Total & 856 & 64 & $61(95.3)$ & 34,527 & 320 & $207(64.2)$ \\
\hline
\end{tabular}




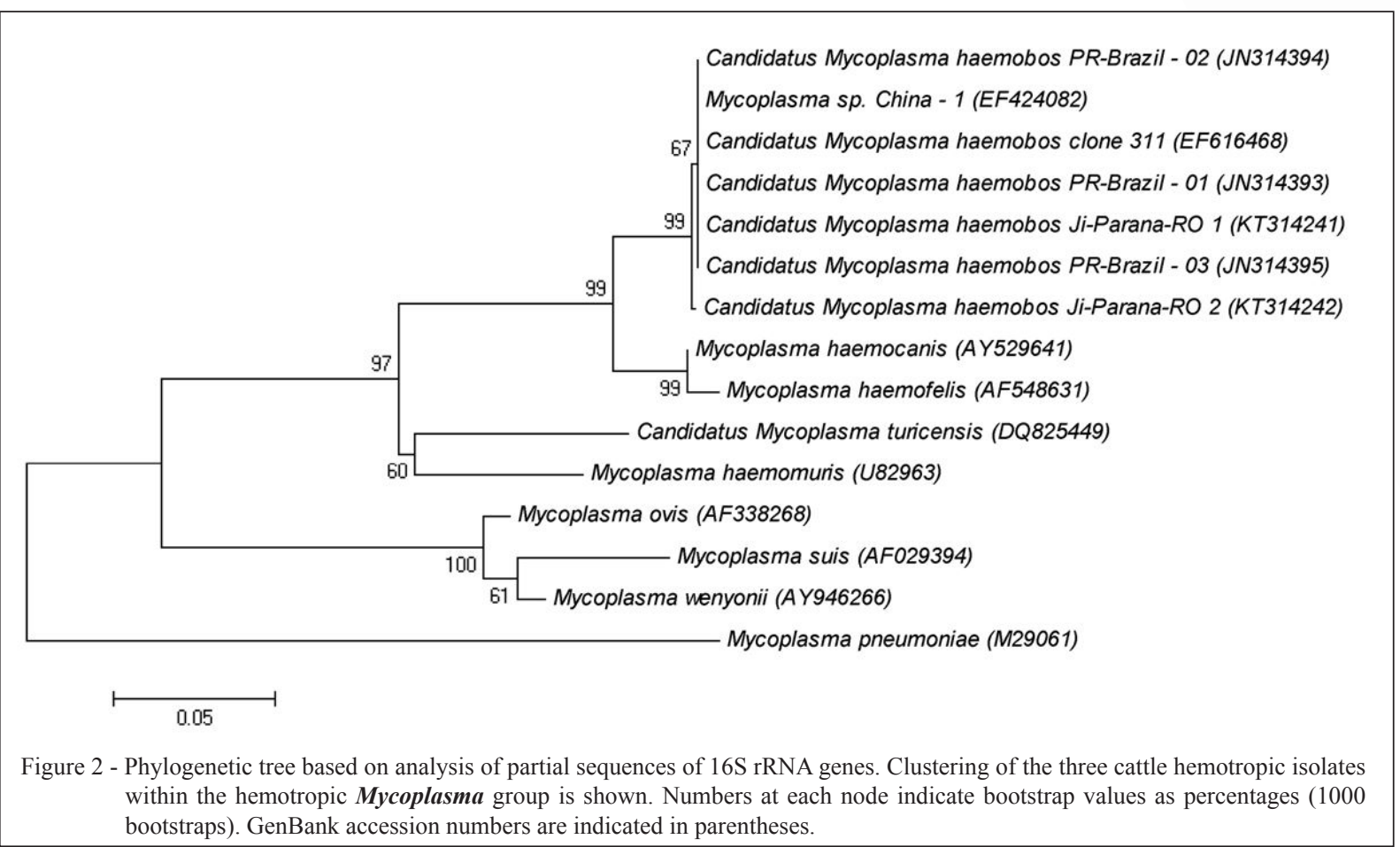

KT314242 ('Ca. M. haemobos' Ji-Parana/RO-2). Phylogenetic analysis revealed that all ' $\boldsymbol{C a}$. M. haemobos' sequences clustered into a single branch (99\% of bootstrap) and the sequences originating from Brazil clustered with those originating from China and Switzerland (Figure 2).

Out of the analyzed herd variables, which included abortion frequency, weak calf birth rates, total cattle number, $>24$-month-old cow number, farm size, and production system, only the number of >24-month-old cows correlated with ' $\boldsymbol{C a}$. M. haemobos' prevalence in the surveyed farms $(\mathrm{P}=0.03723$; Table 2).

\section{DISCUSSION}

The municipality of Ji-Paraná, Rondônia, is one of the major dairy production areas in the north region, Brazil, which makes important to evaluate infectious agents that have the potential to negatively affect productivity in the industry. In the present study, a survey using a specific PCR assay in addition to phylogenetic analysis revealed that ' $\boldsymbol{C} \boldsymbol{a}$. M. haemobos' infection is widespread among dairy herds in family farms, which is a particular production system in the region.

Bovine hemoplasmas are distributed worldwide, and previous studies have shown that
$14.3-83.3 \%$ of cattle have chronic ' $\boldsymbol{C} \boldsymbol{a}$. M. haemobos' infections in Europe, Asia, and Oceania (HOELZLE et al., 2011; TAGAWA et al., 2012; MCFADDEN et al., 2016). However, epidemiological data on ' $\boldsymbol{C a}$. M. haemobos' in the Americas are scarce, with only a single study in southern Brazil which reported similar infection rates as in other countries $(61.0 \%$ of dairy cattle) (GIROTTO et al., 2012), so further investigation is necessary to document infection rates in cattle herds across the country.

High prevalence of ' $\boldsymbol{C} \boldsymbol{a}$. M. haemobos' in $>2$-year-old dairy cattle was expected following reports of TAGAWA et al. (2012) that 1- to 3-year-old cattle are more susceptible to bovine hemoplasmas infection. In addition, GIROTTO et al. (2012) also observed that ' $\boldsymbol{C} \boldsymbol{a}$. M. haemobos' detected by PCR was present at a higher rate in $>2$-year-old female cattle. Indeed, females stay longer in the herd and are consequently more exposed to potential transmission vectors (SMITH et al., 1990).

Furthermore, considering that the number of >24-month-old cows was the only herd variable that correlated with ' $\boldsymbol{C a}$. M. haemobos' prevalence in the surveyed farms, it is notable that fewer than 50 cows existed in those farms where ' $\boldsymbol{C} \boldsymbol{a}$. M. haemobos' was not detected. This suggests that farms with over fifty $>24$-month-old females are at a higher risk of ' $\boldsymbol{C} \boldsymbol{a}$. M. haemobos' infection. However, this tendency was not observed in farms with 
Table 2 - Correlation between 'Candidatus Mycoplasma haemobos' prevalence in dairy cows detected by PCR and the analyzed herd variables.

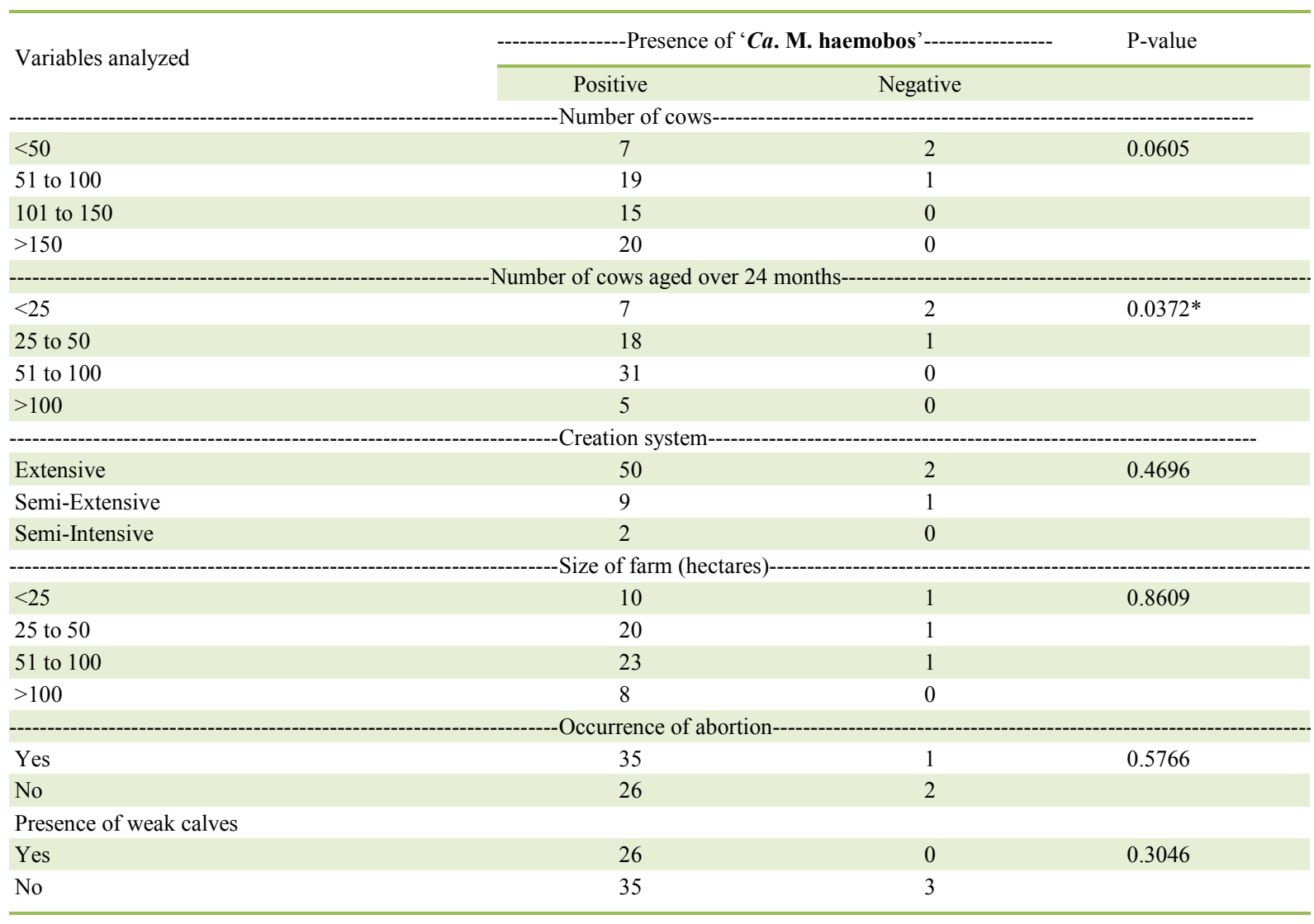

${ }^{*}$ Presence of statistical significance.

more than 100 cows, possibly due to the low proportion $(5 / 64)$ of analyzed farms in this category.

A greater proportion of $>24$-month-old animals can increase the likelihood of infected animals in the herd and, as a consequence of a high presence of infection, transmission of ' $\boldsymbol{C a}$. M. haemobos' via vectors to susceptible dairy cows (SMITH et al., 1990). However, no data currently exists on the involvement of potential vectors in the transmission of 'Ca. M. haemobos' in Brazil, such as dipterans (e.g., Stomoxys calcitrans and Haematobia irritans) as described by HORNOK et al. (2011), and the cattle tick (Rhipicephalus microplus). Thus, the involvement of transmission vectors in ' $\boldsymbol{C} \boldsymbol{a}$. M. haemobos' herd infection rates requires further investigation.

\section{CONCLUSION}

A PCR-based detection method showed that ' $\boldsymbol{C} \boldsymbol{a}$. M. haemobos' prevalence is widespread among dairy herds in the municipality of Ji-Paraná,
Rondônia, mainly in farms with over fifty $>24$-monthold females, which expands distribution of the bacterium in the Americas to the north region, Brazil. Considering the importance of the dairy industry to the areas surveyed in this study, further investigation is necessary to evaluate the effect of these chronically infected animals on milk production and herd health.

\section{ACKNOWLEDGEMENTS}

To Coordenação de Aperfeiçoamento de Pessoal de Nível Superior (CAPES) for the financial support; to Conselho Nacional de Desenvolvimento Científico e Tecnológico (CNPq) for the scholarships of L. Nakazato, V. Dutra, and R.C. Pacheco. To Odilon Vidotto (Universidade Estadual de Londrina) for providing DNA of ' $\boldsymbol{C a}$. M. haemobos'.

\section{BIOETHICS AND COMMITTEE APPROVAL}

BIOSECURITY

Bioethical Committee for Animal Research of the Universidade Federal do Mato Grosso approved the present study, under protocol n. 23108.015662/12-5. 


\section{REFERENCES}

ADLER, S.; ELLENBOGEN, V. A note on two new blood parasites of cattle, Eperythrozoon and Bartonella. Journal of Comparative Pathology, v.47, p.219-221, 1934. Available from: <http://www. sciencedirect.com/science/article/pii/S0368174234800276>. Accessed: Nov. 11, 2015. doi: 10.1016/S0368-1742(34)80027-6.

ALTSCHUL, S.F. et al. Basic local alignment search tool. Journal of Molecular Biology, v.215, p.403-410, 1990. Available from: <http:// www.sciencedirect.com/science/article/pii/S0022283605803602>. Accessed: Nov. 10, 2015. doi: 10.1016/S0022-2836(05)80360-2.

AYLING, R.D. et al. Detection of 'Candidatus Mycoplasma haemobos', Mycoplasma wenyonii and Anaplasma phagocytophilum from cattle in England. Veterinary Record, v.170, p.543a, 2012. Available from: $<$ http://veterinaryrecord.bmj.com/content/170/21/543a. long>. Accessed: Nov. 10, 2015. doi: 10.1136/vr.100636.

BOAS, R.V. et al. Infection by Neospora caninum in dairy cattle belonging to family farmers in the northern region of Brazil. Revista Brasileira de Parasitologia Veterinária, v.24, p.204208, 2015. Available from: <http://dx.doi.org/10.1590/S198429612015035>. Accessed: Nov. 10, 2015. doi: 10.1590/S198429612015035.

GIROTTO, A. et al. Molecular detection and occurrence of 'Candidatus Mycoplasma haemobos' in dairy cattle of Southern Brazil. Revista Brasileira de Parasitologia, v.21, p.342344, 2012. Available from: <http://dx.doi.org/10.1590/S198429612012000300034>. Accessed: Nov. 09, 2015. doi: 10.1590/ S1984-29612012000300034.

HOELZLE, K. et al. Detection of 'Candidatus Mycoplasma haemobos' in cattle with anaemia. Veterinary Journal, v.187, p.408-410, 2011. Available from: <http://www.sciencedirect.com/ science/article/pii/S1090023310000328>. Accessed: Nov. 10, 2015. doi: 10.1016/j.tvj1.2010.01.016.

HORNOK, S. et al. Molecular investigation of transplacental and vector-borne transmission of bovine hemoplasmas. Veterinary Microbiology, v.152, p.411-414, 2011. Available from: <https:// hal.archives-ouvertes.fr/hal-00724197/document>. Accessed: Nov. 12, 2015. doi: 10.1016/j.vetmic.2011.04.031.

MCFADDEN, A. et al. Investigation of bovine haemoplasmas and their association with anaemia in New Zealand cattle. New Zealand Veterinary Journal, v.64, p.65-68, 2016. Available from: <http:// www.tandfonline.com/doi/full/10.1080/00480169.2015.1090356>. Accessed: Jan. 13, 2016. doi: 10.1080/00480169.2015.1090356.

MELI, M.L. et al. Identification, molecular characterization, and occurrence of two bovine hemoplasma species in Swiss cattle and development of real-time TaqMan quantitative PCR assays for diagnosis of bovine hemoplasma infections. Journal Clinical Microbiology, v.48, p.3563-3568, 2010. Available from: <http://
www.ncbi.nlm.nih.gov/pmc/articles/PMC2953077/>. Accessed: Nov. 10, 2015. doi: 10.1128/JCM.02224-09.

MESSICK, J.B. Hemotrophic mycoplasmas (hemoplasmas): a review and new insights into pathogenic potential. Veterinary Clinical Pathology, v.33, p.2-13, 2004. Available from: <http:// onlinelibrary.wiley.com/doi/10.1111/j.1939-165X.2004. tb00342.x/epdf>. Accessed: Nov. 10, 2015. doi: 10.1111/j.1939165X.2004.tb00342.x.

R DEVELOPMENT CORE TEAM. R: a language and environment for statistical computing, reference index version 2.14.0. Vienna: R Foundation for Statistical Computing, 2013. Online. Available from: <http://www.R-project.org>. Accessed: Dec. 11, 2014.

SAMBROOK, J.; RUSSEL, D.W. Molecular cloning: a laboratory manual. New York: Cold Spring Harbor laboratory, 2011. V.3, 2231p.

SMITH, J.A. et al. Eperythrozoon wenyonii infection in dairy cattle. Journal American Veterinary Medicine Association, v.196, p.1244-1250, 1990.

SU, Q.L. et al. The detection of 'Candidatus Mycoplasma haemobos' in cattle and buffalo in China. Tropical Animal Health Production, v.42, p.1805-1808, 2010. Available from: $<$ http://link. springer.com/article/10.1007\%2Fs11250-010-9640-0>. Accessed: Nov. 10, 2015. doi: 10.1007/s11250-010-9640-0.

TAGAWA, M. et al. Molecular detection of Mycoplasma wenyonii and 'Candidatus Mycoplasma haemobos' in cattle in Hokkaido, Japan. Veterinary Microbiology,v.132,p.177-180,2008.Available from: $<\mathrm{http}: / /$ www.sciencedirect.com/science/article/pii/S0378113508001880>. Accessed: Nov. 11, 2015. doi: 10.1016/j.vetmic.2008.05.006.

TAGAWA, M. et al. Comparison of the effect of two hemoplasma species on hematological parameters. Journal of Veterinary Medical Science, v.72, p.113-115, 2010. Available from: $<$ http://doi.org/10.1292/ jvms.090304>. Accessed: Nov. 11, 2015. doi: 10.1292/jvms.09-0304.

TAGAWA, M. et al. Prevalence and risk factor analysis of bovine hemoplasma infection by direct PCR in Eastern Hokkaido, Japan. Journal of Veterinary Medical Science, v.74, p.1171-1176, 2012. Available from: <http://doi.org/10.1292/jvms.12-0118>. Accessed: Nov. 10, 2015. doi: 10.1292/jvms.12-0118.

TAGAWA, M. et al. Effect of chronic hemoplasma infection on cattle productivity. Journal of Veterinary Medical Science, v.75, p.1271-1275, 2013. Available from: <http://www.ncbi.nlm.nih. gov/pmc/articles/PMC3942926/>. Accessed: Nov. 11, 2015. doi: 10.1292/jvms.13-0119.

TAMURA, K. et al. MEGA4: molecular evolutionary genetics analysis (MEGA) software version 4.0. Molecular Biology and Evolution, v.24, p.1596-1599, 2007. Available from: <http://mbe. oxfordjournals.org/content/24/8/1596.long>. Accessed: Dec. 01, 2015. doi: 10.1093/molbev/msm092. 